\title{
GMR
}

\section{Changes on microsatellites of expressed sequence tag of sugarcane (Saccharum spp) during vegetative propagation}

R. Augusto ${ }^{1}$, R.C. Maranho ${ }^{2}$, C.A. Mangolin ${ }^{3}$, J.C. Bespalhok Filho ${ }^{4}$ and M.F.P.S. Machado ${ }^{3}$

${ }^{1}$ Programa de Pós-Graduação em Genética e Melhoramento, Universidade Estadual de Maringá, Maringá, PR, Brasil

${ }^{2}$ Programa de Pós-Graduação em Agronomia, Universidade Estadual de Maringá, Maringá, PR, Brasil

${ }^{3}$ Departamento de Biotecnologia, Genética e Biologia Celular, Universidade Estadual de Maringá, Maringá, PR, Brasil

${ }^{4}$ Departamento de Fitotecnia e Fitossanidade, Universidade Federal do Paraná, Curitiba, PR, Brasil

Corresponding author: M.F.P.S. Machado

E-mail: mfpsmachado@uem.br

Genet. Mol. Res. 16 (1): gmr16019519

Received November 4, 2016

Accepted January 30, 2017

Published March 8, 2017

DOI http://dx.doi.org/10.4238/gmr16019519

Copyright $(2017$ The Authors. This is an open-access article distributed under the terms of the Creative Commons Attribution ShareAlike (CC BY-SA) 4.0 License.

ABSTRACT. The reduction in sugarcane productivity in subsequent
cutting stages may be related to a gradual decrease of the allele number
and mean observed heterozygosity $\left(H_{\mathrm{O}}\right)$ in the sugarcane ratoon. This
hypothesis was tested assessing the number of alleles and $H_{\mathrm{O}}$ values
in 10 expressed sequence tag microsatellites (Est-SSR loci) of the
sugarcane varieties RB72454 and RB867515 in different cutting stages.
Changes of allele numbers in samples of different cutting stages were
observed in seven and six Est SSR loci of the RB72454 and RB867515
varieties, respectively. Reduction of allele numbers was observed in the
samples collected in the fourth and sixth cutting stages of the RB72454

Genetics and Molecular Research 16 (1): gmr16019519 
variety. In contrast, an increase of the allele numbers was detected in the samples collected on fourth, sixth, and seventh cutting stages of the RB867515 variety. Unchanged allele numbers were observed only in EstB41, EstC84, and EstB130 loci of the RB72454 variety, and EstB41, EstC67, EstA68, and EstB130 loci of the RB867515 variety. The variety RB867515 has lower polymorphism and values of $H_{\mathrm{O}}$ than the RB72454 variety in different stages of cutting. At molecular level, in Est-SSR loci, the RB72454 variety showed higher changes in subsequent stages of cutting than RB867515. The similarities and divergences at molecular level between varieties RB72454 and RB867515 observed in the 10 Est-SSR loci during subsequent cutting stages can not explain the reduced productivity frequently observed after subsequent cutting stages but showed that phenotypic and physiological changes after each cutting stage are also accompanied by changes at genomic level.

Key words: Est-SSR polymorphism; Sugarcane varieties; Vegetative propagation; Reduced productivity; Genetic instability

\section{INTRODUCTION}

Microsatellite markers also known as DNA-simple sequence repeats (SSR loci) have been extensively used as molecular markers in sugarcane (Saccharum spp). Although microsatellites have co-dominant inheritance (Tautz, 1989; Weber and May, 1989), the analysis of SSR loci in sugarcane has been especially useful to evaluate genetic distances among sugarcane varieties (Singh et al., 2008, 2011; Oliveira et al., 2009; Duarte-Filho et al., 2010; Liu et al., 2011; Silva et al., 2012). The estimation of genetic diversity within each variety from the mean expected heterozygosity $\left(H_{\mathrm{E}}\right)$ is inaccurate since cultivated sugarcane varieties have one of the most complex plant genomes, carrying variable chromosome numbers (Grivet and Arruda, 2002).

The estimation of genetic diversity within each variety evaluated from the mean observed heterozygosity $\left(H_{\mathrm{O}}\right)$ is plausible but has been little investigated (Maranho et al., 2014). The genetic structure of nine sugarcane varieties using 15 primers for SSR loci identified RB72454 and RB867515 varieties as presenting the highest levels of $H_{\mathrm{O}}$ (Maranho et al., 2014). The RB72454 variety was widely cultivated in Brazil until 2000 and the RB867515 was considered the most widely grown and most cultivated until 2015 for its remarkable features: high productivity and high sucrose content.

Sugarcane cultures are maintained by vegetative propagation via stem cuttings or sections of the stalk. After planting the sugarcane seedlings, the first cut is accomplished within 12-18 months. The annual regrowth of the ratoons ensures the harvest in the cutting stages for about 4 years, or until reduced productivity when becomes necessary the replanting of the sugarcane field (Matos, 2011). The genetic stability in expressed loci for desirable agronomic characteristics is expected during the different cutting stages in order to maintain productivity in the sugarcane varieties. Our objective in the current study was to assess the $H_{\mathrm{O}}$ in expressed sequence tag microsatellites (Est-SSR loci) of the RB72454 and RB867515 varieties to verify if the number of alleles and the heterozygosity levels in each Est-SSR locus are kept during subsequent cutting stages. Changes in allele numbers may suggest the loss or the emergence

Genetics and Molecular Research 16 (1): gmr16019519 
of new alleles while changes in $H_{\mathrm{O}}$ values may suggest variation in allele frequencies in SSR loci associated with agronomic characteristics of interest during the subsequent cutting stages of sugarcane cultures maintained by vegetative propagation.

\section{MATERIAL AND METHODS}

\section{Sugarcane samples}

The sugarcane varieties RB72454 and RB867515 analyzed in the present study were generated from a breeding program at Rede Interuniversitária para o Desenvolvimento do Setor Sucroenergético (RIDESA). The crossing between CP53-76 with an unknown genotype produced the RB72454 while RB867515 was obtained from a crossing between RB72454 with an unknown genotype. Both varieties have been cultivated in Northern Paraná State and supply the ethanol and sugar factories (Fazenda Junqueira, Alto Alegre District in Colorado, PR, Brazil). The selections of samples included 24 plants of the RB72454 variety (eight plants on each cutting stage - second, fourth, and sixth) and 31 plants of the RB867515 variety (seven plants on the second cutting stage and eight plants on fourth, sixth, and seventh cutting stages).

The RB867515 is the most cultivated variety in Brazil occupying $25 \%$ of the total area cultivated with sugarcane in the country while the RB72454 variety was widely cultivated in Brazil until 2000 (Oliveira et al., 2015). The main characteristics of these two cultivars that are especially important for ethanol and sugar production are high productivity and wide adaptability (RB72454) and high yield and sucrose content (RB867515).

\section{Microsatellite selection}

DNA was isolated from the shoots of young leaves of 24 plants of the RB72454 variety (eight plants on each cutting stage - second, fourth, and sixth) and 31 plants of the RB867515 variety (seven plants on the second cutting stage and eight plants on each cutting stage - fourth, sixth, and seventh) according to the procedure used by Hoisington et al. (1994). The five EST-SSR primers (Table 1) previously mapped for sugarcane by the International Sugarcane Microsatellite Consortium (ISMC) (Cordeiro et al., 2000; Singh et al., 2008; Oliveira et al., 2009) were synthesized by Invitrogen Technologies Corporation (USA) and used to analyze the DNA samples from each sugarcane variety. The homologies identified in the database (SUCEST) for the primers ESTB41, ESTC66, ESTC67, ESTC68, ESTC69, ESTC84, ESTC91, ESTB92, ESTB130, and ESTB145 are as follows: a hypothetical protein, a probable xyloglucan endotransglucosylase, $\beta$-amylase, fructose-1,6-bisphosphate aldolase, cellulose synthase 6 , a putative acetyl-CoA C, a putative fructose-1,6-bisphosphatase, a putative sugar transporter, a putative auxin response factor $7 \mathrm{a}$, and $\alpha$-galactosidase-like protein, respectively. Polymerase chain reaction (PCR) was performed using the Techne TC-512 thermal cycler. The amplifications were performed by the Touchdown PCR (Td-PCR) program (Don et al., 1991) using primer-specific annealing temperatures $\left(\mathrm{T}^{\circ} \mathrm{A}\right)$.

For Td-PCR, $20 \mu \mathrm{L}$ volumes containing $25 \mathrm{ng}$ genomic DNA, $10 \mathrm{mM}$ Tris- $\mathrm{HCl}$ at $\mathrm{pH}$ 8.8, $2.0 \mu \mathrm{L}$ 10X reaction buffer $(20 \mathrm{mM}$ Tris- $\mathrm{HCl}$ at $\mathrm{pH}$ 8.0, $0.1 \mathrm{mM}$ EDTA, $1.0 \mathrm{mM}$ DTT, and $50 \%$ (v/v) glycerol), $2.5 \mathrm{mM} \mathrm{MgCl}_{2}, 0.1 \mathrm{mM}$ of each dATP, dGTP, dCTP, and dTTP, $0.3 \mu \mathrm{L}$ of each primer ( $\mathrm{F}$ and $\mathrm{R}$ primers), and $1 \mathrm{U}$ Taq polymerase (Invitrogen) were used.

Genetics and Molecular Research 16 (1): gmr16019519 
Table 1. Sequences of the primers and temperatures of annealing used to amplified the DNA samples from RB72454 and RB867515 varieties; sequence simples repeated (SSR), base pairs, and homologies identified by database SuCEST for each Est-SSR locus.

\begin{tabular}{|c|c|c|c|c|c|c|}
\hline Primer & Sequences & $\mathrm{T}^{\circ} \mathrm{C}$ & Locus & SSR & bp & Data base SUCEST \\
\hline ESTB41 & $\begin{array}{l}\text { F: CATGGAGAGCTGGGCGACCTG } \\
\text { R: GGCGGCGGCGAGGATGA }\end{array}$ & 68 & EstB41 & $(\mathrm{CGA})_{8}$ & 163 & Hypothetical protein \\
\hline ESTC66 & $\begin{array}{l}\text { F: AGTACAGGCTGCTCTCAATCAA } \\
\text { R: TCTGTCATCTGTGTTCGTTCTG }\end{array}$ & 61 & EstC66 & $(\mathrm{CCGC})_{3}$ & 152 & Probable xyloglucan endotransglucosylase \\
\hline ESTC67 & $\begin{array}{l}\text { F: GAGCGAGCCAGTGAGGTCT } \\
\text { R: CCCTCGTCTCGTCCTCCTT }\end{array}$ & 59 & EstC67 & $(\mathrm{AGCC})_{4}$ & 157 & $\beta$-amylase \\
\hline ESTA68 & $\begin{array}{l}\text { F: ACAGTGTTGACCA GTAGGAAGAAT } \\
\text { R: CAGGTACTTGGCGGTCTTG }\end{array}$ & TD & EstA68 & $(\mathrm{CG})_{7}$ & 234 & Fructose 1,6 bisphosphate aldolase \\
\hline ESTC69 & $\begin{array}{l}\text { F:GAACGACGAGCAAGGGAAGGAATG } \\
\text { R: CAATAAGGCAGGACGGAACAGATG }\end{array}$ & TD & EstC69 & $(\mathrm{AAAC})_{4}$ & 159 & Cellulose synthase 6 \\
\hline ESTC84 & $\begin{array}{l}\text { F: AAGCCGGGTTCCAGTCCAG } \\
\text { R: GCAACCAAAAGGCTCAGAACAG }\end{array}$ & TD & EstC84 & $(\mathrm{GCCT})_{4}$ & 204 & Putative acetyl-CoA C \\
\hline ESTC91 & $\begin{array}{l}\text { F: CGAGGACGATGTGGGAGAGG } \\
\text { R: CTCACCTCCCCCAACACAGTC }\end{array}$ & 54 & EstC91 & $(\mathrm{GCCG})_{3}$ & 259 & Putative fructose 1,6 bisphosphatase \\
\hline ESTB92 & $\begin{array}{l}\text { F: TCTGAATGGATGTCGCCCTGTG } \\
\text { R: TTTGCGGGCTTCTCTGCTTTCT }\end{array}$ & TD & EstB92 & $(\mathrm{TTC})_{5}$ & 241 & Putative sugar transporter \\
\hline ESTB130 & $\begin{array}{l}\text { F: GCCCAGGTAATTATCCAGACTC } \\
\text { R: GCTGTTGCTCACTGGTTCC }\end{array}$ & 54 & EstB130 & $(\mathrm{CAA})_{13}$ & 124 & Putative auxin response factor $7 \mathrm{a}$ \\
\hline ESTB145 & $\begin{array}{l}\text { F: GGGAAGCAAGCGAGAGCAGCAGAG } \\
\text { R: GAGCGCGAGGCCGTTGTTGAG }\end{array}$ & 68 & EstB145 & $(\mathrm{CCT})_{5}$ & 234 & $\alpha$-galactosidase-like protein \\
\hline
\end{tabular}

TD: touchdown; Don et al. (1991).

The initial denaturation at $94^{\circ} \mathrm{C}$ for 1 min was followed by 10 cycles of 1 min at $94^{\circ} \mathrm{C}$, 1 min with initial temperature of $65^{\circ} \mathrm{C}$ and a reduction of $1^{\circ} \mathrm{C}$ per cycle, and $2 \mathrm{~min}$ at $72^{\circ} \mathrm{C}$; and 20 cycles of $1 \mathrm{~min}$ at $94^{\circ} \mathrm{C}, 1 \mathrm{~min}$ at $55^{\circ} \mathrm{C}$, and $2 \mathrm{~min}$ at $72^{\circ} \mathrm{C}$. The final extension was 5 min at $72^{\circ} \mathrm{C}$. The PCR using specific temperatures for the primer annealing was $94^{\circ} \mathrm{C}$ for 5 min followed by 30 cycles of $94^{\circ} \mathrm{C}$ for $1 \mathrm{~min}$ and the $\mathrm{T}^{\circ} \mathrm{A}$ of each primer for $1 \mathrm{~min}$, and the later cycles with $72^{\circ} \mathrm{C}$ for $1 \mathrm{~min}$. The final extension was $15 \mathrm{~min}$ at $72^{\circ} \mathrm{C}$.

After amplification, a total of $20 \mu \mathrm{L}$ of each sample was separated by electrophoresis on a $4 \%$ agarose gel ( $50 \%$ agarose and $50 \%$ agarose Metaphor) (CAMBREX) containing $0.5 \mathrm{X}$ TBE buffer (44.5 mM Tris, $44.5 \mathrm{mM}$ boric acid, and $1 \mathrm{mM}$ EDTA). All 72 samples amplified by a single SSR primer were run on the same gel at $60 \mathrm{~V}$ for $4 \mathrm{~h}$. A 1-kb ladder (Invitrogen) was used as a molecular marker weight. The gels were stained using $0.5 \mu \mathrm{g} / \mathrm{mL}$ ethidium bromide, and the image was captured using Molecular Image LOCCUS L-PIX-HE using the Picasa 3 program.

\section{Microsatellite analysis}

Homozygous and heterozygous phenotypes for the different alleles were scored within each Est-SSR locus (EstB41, EstC66, EstC67, EstA68, EstC69, EstC84, EstC91, EstB92, EstB130, and EstB145) in each RB72454 and RB867515 sugarcane variety. The genetic variability within each sugarcane variety was represented by the number of alleles per locus and by the values of mean $H_{0}$. Polyploidy in sugarcane hinders the estimates of allele frequencies found in each locus as well as the values for average $H_{\mathrm{E}}$ for these loci. The polyploidy plants may show heterozygous phenotypes formed by more than two bands, which are products of three or more alleles in loci located on different chromosomes in the polyploidy genome. However, it is possible to detect the proportion of observed homozygous plants as well as the proportion of heterozygous plants containing two or more alleles, so it is possible to estimate the mean $H_{\mathrm{O}}$ for each locus.

Genetics and Molecular Research 16 (1): gmr16019519 


\section{RESULTS}

Polymorphism in the 10 Est-SSR loci of both RB72454 (100\%) and RB867515 (90\%) sugarcane varieties were high. The absence of heterozygous plants and occurrence of one allele was observed only in EstC67 ( $\beta$-amylase; EC 3.2.1.2) locus of the RB867515 variety. The number of alleles and the values of mean $H_{\mathrm{O}}$ for each locus in the samples of RB72454 and RB867515 varieties in each cutting stage (second, fourth, and sixth for RB72454 and second, fourth, sixth, and seventh for RB867515) are shown in Table 2. The $H_{\mathrm{O}}$ values in 10 Est-SSR loci ranged from 0.50 to 0.575 for RB72454 and from 0.50 to 0.5571 for RB867515 varieties. The highest $H_{\mathrm{O}}$ value (100\%) in samples of all cutting stages was observed in EstC66 (a probable xyloglucan endotransglucosylase; EC 2.4.1.207 and/or EC 3.2.1.151) and EstC69 (cellulose synthase 6; EC 2.4.1.29) loci of the RB72454 variety and in the EstC66, EstC69, and EstC91 (a putative fructose-1,6-bisphosphatase; EC 3.1.3.11) loci of the RB867515 variety. The absence of heterozygous in samples of all cutting stages was observed in EstB92 (a putative sugar transporter) and EstB145 ( $\alpha$-galactosidase-like protein) loci of the RB72454 variety and in EstB92, EstB145, and EstC67 loci of the RB867515 variety.

Table 2. Number of alleles $\left(N_{\mathrm{A}}\right)$ and mean observed heterozygosity $\left(H_{\mathrm{O}}\right)$ for each Est-SSR locus of the RB72454 and RB867515 varieties of sugarcane at different cutting stages.

\begin{tabular}{|c|c|c|c|c|c|c|c|c|c|c|c|c|c|c|}
\hline \multirow[t]{3}{*}{ Locus } & \multicolumn{6}{|c|}{ RB72454 } & \multicolumn{8}{|c|}{ RB867515 } \\
\hline & \multicolumn{3}{|c|}{$N_{\mathrm{A}}$} & \multicolumn{3}{|c|}{$H_{\mathrm{O}}$} & \multicolumn{4}{|c|}{$N_{\mathrm{A}}$} & \multicolumn{4}{|c|}{$H_{\mathrm{O}}$} \\
\hline & $2^{\circ}$ & $4^{\circ}$ & $6^{\circ}$ & $2^{\circ}$. & $4^{\circ}$. & $6^{\circ}$. & $2^{\circ}$ & $4^{\circ}$ & $6^{\circ}$. & $7^{\circ}$ & $2^{\circ}$. & $4^{\circ}$. & $6^{\circ}$. & $7^{\circ}$ \\
\hline EstB41 & 2.0 & 2.0 & 2.0 & 1.000 & 0.625 & 0.750 & 2 & 2 & 2 & 2 & 1.000 & 0.8750 & 0.6250 & 1.000 \\
\hline EstC66 & 4.0 & 2.0 & 4.0 & 1.000 & 1.000 & 1.000 & 2 & 4 & 2 & 4 & 1.000 & 1.000 & 1.000 & 1.000 \\
\hline EstC67 & 2.0 & 2.0 & 1.0 & 1.000 & 0.625 & 0.000 & 1 & 1 & 1 & 1 & 0.000 & 0.000 & 0.000 & 0.000 \\
\hline EstA68 & 2.0 & 2.0 & 1.0 & 0.125 & 0.250 & 0.000 & 2 & 2 & 2 & 2 & 0.5714 & 0.000 & 0.000 & 0.000 \\
\hline EstC69 & 4.0 & 4.0 & 2.0 & 1.000 & 1.000 & 1.000 & 2 & 2 & 4 & 4 & 1.000 & 1.000 & 1.000 & 1.000 \\
\hline EstC84 & 2.0 & 2.0 & 2.0 & 0.000 & 0.000 & 0.250 & 1 & 2 & 3 & 3 & 0.000 & 0.2500 & 0.500 & 0.2500 \\
\hline EstC91 & 4.0 & 4.0 & 3.0 & 0.875 & 1.000 & 1.000 & 3 & 3 & 4 & 4 & 1.000 & 1.000 & 1.000 & 1.000 \\
\hline EstB92 & 2.0 & 2.0 & 1.0 & 0.000 & 0.000 & 0.000 & 1 & 2 & 1 & 1 & 0.000 & 0.000 & 0.000 & 0.000 \\
\hline EstB130 & 2.0 & 2.0 & 2.0 & 0.750 & 1.000 & 1.000 & 2 & 2 & 2 & 2 & 1.000 & 1.000 & 0.8750 & 0.8750 \\
\hline EstB145 & 3.0 & 2.0 & 2.0 & 0.000 & 0.000 & 0.000 & 2 & 1 & 2 & 2 & 0.000 & 0.000 & 0.000 & 0.000 \\
\hline Mean & 2.7 & 2.4 & 2.0 & 0.575 & 0.550 & 0.500 & 1.8 & 2.1 & 2.3 & 2.5 & 0.5571 & 0.5125 & 0.5000 & 0.5125 \\
\hline
\end{tabular}

Changes of $H_{\mathrm{O}}$ values in samples from different cutting stages (second, fourth, and sixth in RB72454 variety, and second, fourth, sixth, and seventh in RB867515 variety) were observed in 6 of the 10 Est-SSR loci (EstB41, EstC67, EstA68, EstC84, EstC91, and EstB130) of the RB72454 variety (Table 2), and only in 4 of the 10 Est-SSR loci (EstB41, EstA68, EstC84, and $E s t B 130$ ) of the RB867515 variety. Thereby, the levels of $H_{\mathrm{O}}$ estimated for sugarcane, as well as the numbers of alleles detected, are dependent on the Est-SSR locus, cutting stage, and variety. While the EstC67 locus is monomorphic in samples from second, fourth, sixth, and seventh cutting stages of the RB867515 variety, it is polymorphic suggesting different allele frequencies in samples from second, fourth, and sixth cutting stages of the RB72454 variety.

Changes of allele numbers in samples of different cutting stages were observed in 7 (EstC66, EstC67, EstA68, EstC69, EstC91, EstB92, and EstB145) and 6 (EstC66, EstC69, EstC84, EstC91, EstB92, and EstB145) Est-SSR loci of the RB72454 and RB867515 varieties, respectively. Reduction of allele numbers was observed in the Est-SSR loci of the samples collected in the fourth and sixth cutting stages of the RB72454 variety (Table 2). In contrast, an increase of the allele numbers was detected in the Est-SSR loci of the samples collected on

Genetics and Molecular Research 16 (1): gmr16019519 
fourth, sixth, and seventh cutting stages of the RB867515 variety. Unchanged allele numbers in samples of different cutting stages were observed only in EstB41, EstC84, and EstB130 loci of the RB72454 variety, and EstB41, EstC67, EstA68, and EstB130 loci of the RB867515 variety.

Accordingly, the variety RB867515 has lower polymorphism and values of $H_{\mathrm{O}}$ than the RB72454 variety in different stages of cutting. So, the variety RB72454 can be characterized as having higher $H_{\mathrm{O}}$ than the RB867515 variety in the SSR contained within expressed sequences (loci EstB41, EstC66, EstC67, EstA68, EstC69, EstC84, EstC91, EstB92, EstB130, and EstB145). The RB72454 variety has also the highest number of Est-SSR loci with changes of allele number and values of $H_{\mathrm{O}}$ in different cutting stages. At molecular level, in SSR of expressed sequences, the RB72454 variety showed higher changes in subsequent stages of cutting than RB867515.

\section{DISCUSSION}

Despite high polymorphism, lower $H_{\mathrm{O}}$ values were detected in Est-SSR loci of both varieties RB72454 ( $\left.\mathrm{P}=100 \% ; H_{\mathrm{O}}=0.50-0.575\right)$ and $\mathrm{RB} 867515\left(\mathrm{P}=90 \% ; H_{\mathrm{O}}=0.50-\right.$ 0.5571) than in SSR of noncoding loci as previously reported by Maranho et al. (2014) for $\mathrm{RB} 72454\left(\mathrm{P}=100 \% ; H_{\mathrm{O}}=0.833\right)$ and $\mathrm{RB} 867515$ varieties $\left(\mathrm{P}=93.75 \% ; H_{\mathrm{O}}=0.7920\right)$. In contrast to the lowest values of $H_{\mathrm{O}}$ detected in the 10 Est-SSR loci, the highest $H_{\mathrm{O}}$ values were detected in SSR from the locus probably coding xyloglucan endotransglucosylase (EC 2.4.1.207 and/or EC 3.2.1.151) (locus EstC66) and in SSR from the locus coding a cellulose synthase (EC 2.4.1.29) (locus EstC69). The xyloglucan endotransglucosylase as well as the cellulose synthase are enzymes directly involved in the construction, growth, and cell wall extensibility (Takeda et al., 2002; Doblin et al., 2002; Festucci-Buselli et al., 2007; Miedes et al., 2011; Hara et al., 2014) since the long polysaccharide xyloglucan can form hydrogen bonds with cellulose microfibrils. The xyloglucan endotransglucosylase/ hydrolase genes are also involved with defense and pathogen-resistance mechanisms (Sharmin et al., 2012; Olsen et al., 2016). So that the EstC66 and EstC69 loci in the RB72454 and RB867515 varieties are examples of important coding sequences associated with agronomic characteristics of interest, which contain SSR presenting $100 \% H_{\mathrm{O}}$. High polymorphism in SSR of the cellulose synthase locus observed also in other sugarcane varieties was used to explain the high variability of substrates used in pretreatment and in enzymatic hydrolysis processes of their respective bagasse fibers in order to obtain the fermentable sugars to produce ethanol (Augusto et al., 2015). The SSR in the EstC91 locus for a putative fructose-1,6-bisphosphatase also showed $100 \% H_{\mathrm{O}}$ in the RB867515 variety. The fructose 1,6-bisphosphatase (EC 3.1.3.11) is an important enzyme that had a positive effect on the pathway of carbon fixation and photosynthesis (Chueca et al., 2002; Tamoi et al., 2006).

Despite the high degree of relatedness between the varieties RB72454 and RB867515 (RB72454 variety is the female parent of the RB867515 variety), differences in the $H_{\mathrm{O}}$ values are observed at the EstC67, EstC68, EstC84, EstC91, and EstB130 loci in samples collected in different cutting stages. Pronounced differences at molecular level between the varieties RB72454 and RB867515 are observed in the subsequent cutting stages. While the mean number of alleles decreased from the second to the sixth cutting stage in the RB72454 variety, an increase of the mean number of alleles has occurred from the second to the seventh

Genetics and Molecular Research 16 (1): gmr16019519 
cutting stage in the 10 Est-SSR loci of the RB867515 variety. Changes in the allele frequencies (indicated by different values of $H_{\mathrm{O}}$ ) in six Est-SSR loci (EstB41, EstC67, EstA68, EstC84, EstC91, and EstB130) of the RB72454 variety and four Est-SSR loci (EstB41, EstA68, EstC84, and EstB130) of the RB867515 variety also point out the molecular divergence between both varieties. The different number of chromosomes of both varieties should be one of the factors that may be used to justify a divergence at molecular level. The chromosome number of the RB72454 variety $(2 \mathrm{n}=112$; amplitude of $108-114)$ is higher than the number reported for the RB867515 variety $(2 \mathrm{n}=110$; amplitude $105-114)$.

Within each variety RB72454 and RB867515, somatic mutations may lead to the appearance of new alleles while somatic recombination may lead to loss of alleles and/or reduction of heterozygous phenotypes in the vegetative propagation after each cutting stage. Somatic mutations in vegetative-propagated plants are relatively frequent natural events reported since the 90 s of the last century (Franks et al., 2002; Vouillamoz et al., 2003), which have been recently evident at DNA level (Vezzulli et al., 2012). The occurrence of somatic recombination in addition to somatic mutations in grapes that were vegetatively propagated was reported as an event that may promote gene homozygosis in the heterozygous condition (Oliveira-Collet et al., 2005). It is possible that transposable genetic elements described in the genomes of $S$. officinarum and S. spontaneum (de Souza et al., 2013), can mediate the chromosomal rearrangements in the varieties of Saccharum spp. Epigenetic variability due to differential methylation levels in a complex genome as the sugarcane may also lead to genotypic and phenotypic instability (Marfil et al., 2009). Also due to differential methylation events, mechanisms of successive silencing of genes, such as the ones observed in in vitro vegetative propagation (Nocarova et al., 2010), may lead to a reduction of heterozygous phenotypes. Such alterations (one or more than one) imply in genetic instability and deserve further investigation.

The similarities and divergences at molecular level between varieties RB72454 and RB867515 observed in the 10 Est-SSR loci during subsequent cutting stages can not explain the reduced productivity frequently observed after subsequent cutting stages but showed that phenotypic and physiological changes after each cutting stage are also accompanied by changes at genomic level.

There are few features of interest to the producer (harvest time, closing between lines, growth rate, exigency of environments, until industrialization period) that differentiate RB72454 and RB867515 varieties. Both varieties have high sucrose content and medium content of fibers (Daros et al., 2015). The similar pattern for fiber content in RB72454 and RB867515 varieties is consistent with the same level of heterozygosity detected in the EstC66 (probable xyloglucan endotransglucosylase) and EstC69 (cellulose synthase 6) loci and with the genetic stability observed at these loci during the cutting stages. The samples of RB72454 variety showed higher polymorphism, higher values of $H_{\mathrm{O}}$, and higher number of Est-SRR loci with changes in the subsequent cutting stages than the RB867515 variety.

The high heterozygosity of the RB72454 variety is consistent with its utility as parental in breeding programs. Santos et al. (2012) listed the RB72454 variety as parental (female or male) in more of $30 \%$ of crosses for generation of new varieties of the germplasm bank of Serra do Ouro, maintained by the Genetic Improvement Program for Sugarcane at the Federal University of Alagoas, Brazil. According to Daros et al. (2015) RB72454 gave rise to 25 new varieties RB and it was one of the most cultivated varieties in Brazil until 2010, when the area was reduced due to 'orange rust' infestation.

Genetics and Molecular Research 16 (1): gmr16019519 
Although the heterozygosity of the RB867515 in 10 loci Est-SSR is somewhat lower than the observed in the RB72454 variety, the $H_{\mathrm{O}}$ of the RB867515 seems to be sufficient to confer a high adaptive potential to the RB867515 variety. The RB867515 is the most cultivated variety in Brazil occupying $25 \%$ of the total area cultivated with sugarcane in the country. The 2015 census showed the RB867515 variety in: i) first place in $46.6 \%$ of states (regions South, Southeast, and Midwest) where sugarcane is cultivated; ii) second place in $33.33 \%$ of the states (Northeast region); and iii) third place in $20 \%$ of the states (also in Northeast region) (Oliveira et al., 2015).

Although the real factors related with the changes of number of alleles and values of $H_{\mathrm{O}}$ in the different cutting stages of each RB72545 and RB867515 varieties are unknown, the evidence of such changes have important practical implications. It is needed prudence in studies to evaluate the genetic similarity between pairs of sugarcane genotypes destined for breeding programs. Different values of genetic identity may be expected, e.g., in comparison between samples of RB72454 variety in the second cutting stage $\left(\mathrm{Na}=2.7 ; H_{\mathrm{O}}=0.5750\right)$ with the RB867515 variety from the same cutting stage $\left(\mathrm{Na}=1.8 ; H_{\mathrm{O}}=0.5571\right)$ or from the sixth cutting stage $\left(\mathrm{Na}=2.3 ; H_{\mathrm{O}}=0.5000\right)$.

The estimated values for the 10 Est-SSR loci of the RB72454 and RB867515 varieties confirmed our expectations to find lower values than those described in SSR of non-coding DNA regions. On the other hand, it was possible to identify SSR with $100 \%$ of heterozygosity at loci which encode important enzymes associated with agronomic traits of interest. The high heterozygosity in these loci seems to be maintained in samples of subsequent cutting stages (second, fourth and sixth cutting stages in RB72454 variety and second, fourth, sixth, and seventh cutting stages in RB867515 variety), while in others Est-SSR loci occurred absence of heterozygous or variations in the number of alleles and of the $H_{\mathrm{O}}$ values during the vegetative propagation of sugarcane. The values of $H_{\mathrm{O}}$ at the 10 Est-SSR loci of both varieties RB72454 and RB867515 has decreased from the second to the sixth cutting stage suggesting that a decrease on the mean $H_{\mathrm{O}}$ may be related to reduction in sugarcane productivity in subsequent cutting stages during its vegetative propagation. According to this, there is now the suspicion that the reduction in sugarcane productivity in subsequent cutting stages may be due to a gradual decrease of the mean $H_{\mathrm{O}}$ in the sugarcane ratoon.

The conclusion and recommendation from our study is that the comparison among different sugarcane varieties in order to find the contrasting genotypes should be made using varieties in the same cutting stage since that changes in the number of alleles and in the allele frequencies (indicated by different values of $H_{\mathrm{O}}$ ) has been observed in expressed sequence tag microsatellites (Est-SSR loci) of sugarcane in different cutting stages during the vegetative propagation. Therefore, it is needed prudence in studies to evaluate the genetic similarity between pairs of sugarcane genotypes destined for breeding programs. Moreover, polymorphisms in Est-SSR loci associated with sugar and ethanol production during the sugarcane vegetative propagation may mark different sugar and ethanol production in different cutting stages.

\section{ACKNOWLEDGMENTS}

The authors would like to thank CAPES (Coordenação de Aperfeiçoamento de Pessoal de Nível Superior, Brasília, DF, Brazil) for the financial support.

Genetics and Molecular Research 16 (1): gmr16019519 
Changes at genomic level during vegetative propagation

\section{REFERENCES}

Augusto R, Maranho RC, Mangolin CA and Pires da Silva Machado MdeF (2015). High polymorphism in Est-SSR loci for cellulose synthase and b-amylase of sugarcane varieties (Saccharum spp.) used by the industrial sector for ethanol production. Appl. Biochem. Biotechnol. 175: 965-973.- http://dx.doi.org/10.1007/s12010-014-1340-1

Chueca A, Sahrawy M, Pagano EA and López Gorgé J (2002). Chloroplast fructose-1,6-bisphosphatase: structure and function. Photosynth. Res. 74: 235-249.- http://dx.doi.org/10.1023/A:1021243110495

Cordeiro GM, Taylor GO and Henry RJ (2000). Characterisation of microsatellite markers from sugarcane (Saccharum sp.), a highly polyploid species. Plant Sci. 155: 161-168.- http://dx.doi.org/10.1016/S0168-9452(00)00208-9

Daros E, Oliveira RA and Barbosa GVS (2015). 45 anos de variedades RB de cana-de-açúcar. 25 anos de RIDESA. Editora Graciosa, Curitiba.

de Souza MC, Silva JN and Almeida C (2013). Differential detection of transposable elements between Saccharum species. Genet. Mol. Biol. 36: 408-412.- http://dx.doi.org/10.1590/S1415-47572013005000030

Doblin MS, Kurek I, Jacob-Wilk D and Delmer DP (2002). Cellulose biosynthesis in plants: from genes to rosettes. Plant Cell Physiol. 43: 1407-1420.= http://dx.doi.org/10.1093/pcp/pcf164

Don RH, Cox PT, Wainwright BJ, Baker K, et al. (1991). 'Touchdown' PCR to circumvent spurious priming during gene amplification. Nucleic Acids Res. 19: 4008.- http://dx.doi.org/10.1093/nar/19.14.4008

Duarte-Filho LSC, Silva PP, Santos JM, Barbosa GVS, et al. (2010). Genetic similarity among genotypes of sugarcane estimated by SSR and coefficient of parentage. Sugar Tech 12: 145-149. http://dx.doi.org/10.1007/s12355-010-0028-2

Festucci-Buselli RA, Otoni WC and Joshi CP (2007). Structure, organization, and functions of cellulose synthase complexes in higher plants. Braz. J. Plant Physiol. 19: 1-13. http://dx.doi.org/10.1590/S1677-04202007000100001

Franks T, Botta R, Thomas MR and Franks J (2002). Chimerism in grapevines: implications for cultivar identity, ancestry and genetic improvement. Theor. Appl. Genet. 104: 192-199.- http://dx.doi.org/10.1007/s001220100683

Grivet L and Arruda P (2002). Sugarcane genomics: depicting the complex genome of an important tropical crop. Curr. Opin. Plant Biol. 5: 122-127.- http://dx.doi.org/10.1016/S1369-5266(02)00234-0

Hara Y, Yokoyama R, Osakabe K, Toki S, et al. (2014). Function of xyloglucan endotransglucosylase/hydrolases in rice. Ann. Bot. (Lond.) 114: 1309-1318.- http://dx.doi.org/10.1093/aob/mct292

Hoisington D, Khairallah M and González-Léon D (1994). Laboratory Protocols: CIMMYT Applied Molecular Genetics Laboratory. 2nd edn. CIMMYT, Mexico, D.F.

Liu P, Que Y and Pan Y-B (2011). Highly polymorphic microsatellite DNA markers for sugarcane germplasm evaluation and variety identity testing. Sugar Tech 13: 129-136. http://dx.doi.org/10.1007/s12355-011-0077-1

Maranho RC, Augusto R, Mangolin CA and Machado MFPS (2014). Use of differential levels of mean observed heterozygosity in microsatellite loci of commercial varieties of sugarcane (Saccharum spp). Genet. Mol. Res. 13: 10130-10141.- http://dx.doi.org/10.4238/2014.December.4.7

Marfil CF, Camadro EL and Masuelli RW (2009). Phenotypic instability and epigenetic variability in a diploid potato of hybrid origin, Solanum ruiz-lealii. BMC Plant Biol. 9: 21.- http://dx.doi.org/10.1186/1471-2229-9-21

Matos CRA (2011). Secretaria do Meio Ambiente/Coordenadoria de Biodiversidade e Recursos Naturais. Etanol e Biodiesel. SMA, São Paulo.

Miedes E, Zarra I, Hoson T, Herbers K, et al. (2011). Xyloglucan endotransglucosylase and cell wall extensibility. J. Plant Physiol. 168: 196-203.= http://dx.doi.org/10.1016/j.jplph.2010.06.029

Nocarova E, Opatrny Z and Fischer L (2010). Successive silencing of tandem reporter genes in potato (Solanum tuberosum) over 5 years of vegetative propagation. Ann. Bot. (Lond.) 106: 565-572.- http://dx.doi.org/10.1093/aob/mcq153

Oliveira KM, Pinto LR, Marconi TG, Mollinari M, et al. (2009). Characterization of new polymorphic functional markers for sugarcane. Genome 52: 191-209.= http://dx.doi.org/10.1139/G08-105

Oliveira RA, Daros E and Hoffmann HP (2015). Liberação Nacional de Variedades RB de Cana-de-açúcar. Editora Graciosa, Curitiba.

Oliveira-Collet SA, Collet MA and Machado MFPS (2005). Differential gene expression for isozymes in somatic mutants of Vitis vinifera L. (Vitaceae). Biochem. Syst. Ecol. 33: 691-703. http://dx.doi.org/10.1016/j.bse.2004.12.016

Olsen S, Striberny B, Hollmann J, Schwacke R, et al. (2016). Getting ready for host invasion: elevated expression and action of xyloglucan endotransglucosylases/hydrolases in developing haustoria of the holoparasitic angiosperm Cuscuta. J. Exp. Bot. 67: 695-708.- http://dx.doi.org/10.1093/jxb/erv482

Santos JM, Duarte Filho LSC, Soriano ML, Silva PP, et al. (2012). Genetic diversity of the main progenitors of sugarcane from the RIDESA germplasm bank using SSR markers. Ind. Crops Prod. 40: 145-150. http://dx.doi.org/10.1016/j. indcrop.2012.03.005

Sharmin S, Azam MS, Islam MS, Sajib AA, et al. (2012). Xyloglucan endotransglycosylase/hydrolase genes from a

Genetics and Molecular Research 16 (1): gmr16019519 
susceptible and resistant jute species show opposite expression pattern following Macrophomina phaseolina infection. Commun. Integr. Biol. 5: 598-606.- http://dx.doi.org/10.4161/cib.21422

Silva DC, Duarte Filho LSC, Santos JM, Barbosa GV, et al. (2012). DNA fingerprinting based on simple sequence repeat (SSR) markers in sugarcane clones from the breeding program RIDESA. Afr. J. Biotechnol. 11: 4722-4728.

Singh RK, Srivastava S, Singh SP, Sharma ML, et al. (2008). Indentification of new microsatellites DNA markers for sugar and related traits in sugarcane. Sugar Tech 10: 327-333. http://dx.doi.org/10.1007/s12355-008-0058-1

Singh RK, Singh RB, Singh SP and Sharma ML (2011). Identification of sugarcane microsatellites associated to sugar content in sugarcane and transferability to other cereal genomes. Euphytica 182: 335-354. http://dx.doi.org/10.1007/ $\underline{\mathrm{s} 10681-011-0484-0}$

Takeda T, Furuta Y, Awano T, Mizuno K, et al. (2002). Suppression and acceleration of cell elongation by integration of xyloglucans in pea stem segments. Proc. Natl. Acad. Sci. USA 99: 9055-9060.- http://dx.doi.org/10.1073/ pnas.132080299

Tamoi M, Nagaoka M, Miyagawa Y and Shigeoka S (2006). Contribution of fructose-1,6-bisphosphatase and sedoheptulose-1,7-bisphosphatase to the photosynthetic rate and carbon flow in the Calvin cycle in transgenic plants. Plant Cell Physiol. 47: 380-390.- http://dx.doi.org/10.1093/pcp/pcj004

Tautz D (1989). Hypervariability of simple sequences as a general source for polymorphic DNA markers. Nucleic Acids Res. 17: 6463-6471.= http://dx.doi.org/10.1093/nar/17.16.6463

Vezzulli S, Leonardelli L, Malossini U, Stefanini M, et al. (2012). Pinot blanc and Pinot gris arose as independent somatic mutations of Pinot noir. J. Exp. Bot. 63: 6359-6369.- http://dx.doi.org/10.1093/jxb/ers290

Vouillamoz J, Maigre D and Meredith CP (2003). Microsatellite analysis of ancient alpine grape cultivars: pedigree reconstruction of Vitis vinifera L. 'Cornalin du Valais'. Theor. Appl. Genet. 107: 448-454.- http://dx.doi.org/10.1007/ $\underline{\mathrm{s} 00122-003-1265-5}$

Weber JL and May PE (1989). Abundant class of human DNA polymorphisms which can be typed using the polymerase chain reaction. Am. J. Hum. Genet. 44: 388-396.=

Genetics and Molecular Research 16 (1): gmr16019519 